\title{
Elegy for the Little Jewish Towns (Elegia miasteczek żydowskich)
}

\author{
Author: Antoni Słonimski
}

First Published: 1951 in: Poezje, Warszawa: Czytelnik.

Translations: English (Elegy for the Little Jewish Towns,1951); Hebrew (ha-Kina al ha'ayarot ha-yehudiot, 1957); German (Klagelied für die jüdischen Schtetl, 1961); French (Elégie pour les villages juifs, 1962).

Music Adaptations: Szymon Laks, Elegia miasteczek żydowskich, Kraków: Wydawnictwo Muziczne, 1963 (adapted in 1961); Antonina Krzysztoń, Elegia żydowskich miasteczek, in: Czas bez skarg, music disc, Warszawa: Pomaton 1995; Tomasz Gwinciński, Paweł Szamburski, Jurij Jaremczuk, Patryk Zakrocki et al., Sztetlach, music disc, Dembitzer Music: Dębica, 2005.

About the Author: Antoni Słonimski (1895-1976) was born in Warsaw in a Polish-Jewish family of prominent intellectuals. He graduated the Warsaw School of Fine Arts (1917) and exhibited his artistic works at numerous group and individual exhibitions before the war. He collaborated with satirical weeklies, co-founded the famous cabaret Pikador (1918) and co-created the famous and influential avant-garde poetry group Skamander (1919). As a columnist (especially as the author of the well-known "Weekly Chronicle” for Wiadomości Literackie), he expressed the views of the liberal intelligentsia, rationalists and sceptics, and confronted racial and national prejudices, especially fascism. During the war he stayed in Paris and London, returning to Poland in 1951. He printed articles, poems and columns in magazines and was a member of the board of the Polish PEN Club. In addition to working with UNESCO, Słonimski took part in a number of democratic opposition actions and openly criticised the authorities during the events of 1968.

Further Important Publications: Rodzina (1933, The Family; poems); Dwa końce świata (1937, Two Ends of the World; novel); Wspomnienia warszawskie (1957, Warsaw Memories; memoirs); Sąd nad Don Kichotem (1965, Court over Don Quixote; poem); Alfabet wspomnien (1975, The Alphabet of the Memories; memoirs).

\section{Content and Interpretation}

The poem was composed by Słonimski during his immigration to England in 1947. It is written in the classic form of six four-legged verses made up of thirteen-syllable lines. Classical order conveys a sense of the sublime, but it also soothes emotions: a nostalgic gesture that bids farewell to a world that has been destroyed. The poet Anna Kamieńska wrote in the late 1970s that "Elegy for Little Jewish Towns is a lamentation after a cruel pogrom. It is a poem that would remain of Słonimski’s entire output, even

Ә Open Access. () 2021 Agata Firlej, published by De Gruyter. (c) BY-NC-ND This work is licensed under a Creative Commons Attribution-NonCommercial-NoDerivatives 4.0 License. https://doi.org/10.1515/9783110671056-034 
if the rest drowned and faded" (Kamieńska, 1977, p. 46). Yet it must be pointed out that the question of the pogrom (and of the Shoah) in Słonimski's poem, contrary to Kamieńska's assessment, is raised in the subtlest way, perhaps for fear of "appropriating” an experience of collective suffering that Słonimski, living in exile, only witnessed from afar, but perhaps also in recognition of the unseemliness of any aesthetic or artistic attempt to describe the Shoah. Thus, the centre of gravity of the poem and its general idea tend towards the future, not the wartime past. Bartłomiej Krupa (like Michael C. Steinlauf) remarks that the opening verses of this poem serve as an epigraph for almost every other text devoted to the history of local Jews, especially in the 1980s and 1990s - proof positive of a nostalgic literary formula for writing about this community. If so, it is a formula Słonimski co-founded. Recalling the first lines of Słonimski's text, Krupa suggests that these verses introduce a sentimental, prayerful mood based on the recollection of the Jewish presence in the setting of small towns, which still exist in a certain sense under an unchanged name. Analysing the last verses of the work, Krupa notes how they are constructed in such a way as to convey a simple message: that two nations living in proximity to one another, Polish and Jewish, co-existed during the interwar period in peace and amity, and that only war and the Holocaust, which came from outside, ended this symbiosis. In fact, attendant on this message, the poem seems to convey a certain optimism, as if to say that it is only due to these outside influences, the shadow of the Holocaust, that the close relationship between Poles and Jews has been lost - not forever, however, because there is still hope for a future, as the closing lines of Słonimski's poem claim, where the two nations will "come together fraternally and unite again". Krupa indicates that here are two rhetorical conventions deployed in Elegy: the rhetoric of suffering that brings people together and the rhetoric of local, multicultural communities living in harmony. Over the last three decades, these conventions have come under increased scrutiny by researchers who have come to consider them naive - perhaps even, in the light of historical research, completely off base. Słonimski's poem is an important testimony of a certain myth perpetuated in the minds of Poles and Polish Jews after the war (see Krupa, 2013, pp. 226-227).

The poem is also significant for artistic reasons: it is a song mourning narration, the loss of a world that never existed, by means of a unique lyricism. As Magdalena Ładon pointed out, the phrase "no way" appears in the poem as many as five times, in connection to such words as "vain", "leftovers", "last" and "disappeared", and to such phrases as "they will not find" and "have gone away". This all seems to point to a conscious mythologisation of the non-existent little towns. The evolution in describing the shtetl tends to present it as an unreal place, "enchanted in time"; it is a place associated with the transference of a tangible reality, remembered by the author or learned through his relations with others individual memory, into the realm of the literary imagination. Shtetl, at the moment when Słonimski writes his poem, is considered to be a town of the dead, and so the poet is compelled to create a "funeral lament", as Natan Gross describes Elegy. The work is dominated by the aesthetics of 
nostalgia, which arises from a certain dissonance between the past and the present. As such, it is reminiscent of certain works of art with which Słonimski, an artist himself, would have surely been familiar: the visions of Marc Chagall, for example, whose nostalgia, lyricism, magic, and sadness co-create the "mythisational" potential of Elegy.

\section{Main Topics and Problems}

Antoni Słonimski, writing the Elegy for the Little Jewish Towns, adds his voice to other poetic confessions concerning the tragedy of the Shoah. At the same time, however, it is a gesture connected with the personal experiences which the author himself witnessed. In this regard, it is worth turning our attention to the pre-war years, to the 1930s when Słonimski's texts dealt primarily with the rise of fascism, which he considered as the biggest threat. The author then became the object of attacks by Polish nationalist groups, pointing out his Jewish origins. When in 1938 he published the poem Two Homelands, proclaiming his "Jagiellonian" patriotism, open to various attitudes, nationalities and religions, he was publicly slapped by the right-wing writer Zygmunt Ipohorski.

Thus Elegy can be conceived as a lamentation with a resounding personal dimension. Its specifics and mythisational character can be easily seen in the background of the text $\rightarrow$ We, Polish Jews, published in New York in 1945 by Julian Tuwim. While the lyricism of Słonimski's verse aims to produce a certain emotional tension, to evoke - and say farewell to - a lost world that the poet considers as his own point of origin, Tuwim (also a Polish Jew) regards the whole post-war situation differently. "I am Polish, because I like it that way", he declares, which has been considered as a testimony to the final formation of the poet's Jewish identity. Słonimski, unlike Tuwim, never had problems with his double identity; he defined himself as Polish all his life, but he proudly spoke about his Jewish ancestors. Emphasising the different situation of Tuwim, his biographer Piotr Matywiecki writes: "Certainly Antoni Słonimski was someone different coming from a family assimilated culturally and religiously for generations, Józef Wittlin was also someone different. He intellectualised his first Jewishness, and the second he made the centre of his ethical attitude - the attitude of a Christian.” (Matywiecki, 2007, p. 316)

The Elegy of Antoni Słonimski, on the one hand, is a component of a nostalgic myth that was created in Polish literature after the war, and on the other, it can be read as proof of the diversity of attitudes and identities of Polish Jews.

\section{Cited Works}

Kamieńska, A. (1977). Czytając Słonimskiego. Twórczość, 20(6), pp. 35-55. Krupa, B. (2013). Opowiedzieć Zagładę. Polska proza i historiografia wobec Holocaustu (19872003). Universitas: Kraków. Lipszyc Jarosław, Miasteczka 2.1, available at: www.dembitzer.pl/img/File/miasteczka2_1.pdf [Accessed 10.07.2019]. Matywiecki, P. (2007). Twarz Tuwima. Warszawa: WAB. 


\section{Further References}

Gross, N. (1993). Poeci i Szoa. Obraz Zagłady Żydów w poezji polskiej. Sosnowiec: Offmax. Hutnikiewicz, A. (1977). Słonimski. Twórczość, 20(6), pp. 20-34. Kowalczykowa, A. (1973). Stonimski. Warszawa: Agencja Autorska i Zjednoczenie Księgarstwa. Kumaniecka, J. (2003). Saga rodu Stonimskich. Warszawa: Iskry. Rudnicki, A. (1981). Rogaty warszawiak. Kraków: Wydawnictwo Literackie. Sandauer, A. (1977). Wiek zwycięstw. In: A. Sandauer, Poeci czterech pokoleń. Kraków: Wydawnictwo Literackie. Steinlauf, M. C. (1997). Bondage to the Dead: Poland and the Memory of the Holocaust. Sycaruse NY: Syracuse University Press. Opacki, I., Węgrzyniak, A., eds. (1988). Studia o twórczości Antoniego Stonimskiego. Katowice: Uniwersytet Śląski. Kądziela, P., Międzyrzecki, A., eds. (1996). Wspomnienia o Antonim Stonimskim. Warszawa: Biblioteka „Więzi“.

$\mathrm{AF}$ 